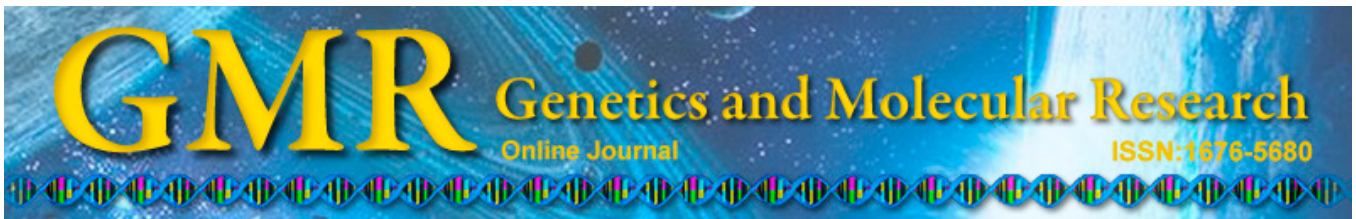

\title{
Establishment of a prediction model for the miRNA-based heading date characteristics of rice in the booting stage
}

\author{
Y.C. Chen ${ }^{1}$, W.S. Lin ${ }^{1}$, R.K. Chen ${ }^{2}$, Y.Y. Chao ${ }^{1}$, S.W. Chin ${ }^{1}$, F.C. Chen ${ }^{1}$ \\ and C.Y. Lee ${ }^{1}$ \\ ${ }^{1}$ Department of Plant Industry, \\ National Pingtung University of Science \& Technology, Pingtung, Taiwan \\ ${ }^{2}$ Tainan District Agricultural Research and Extension Station, \\ Council of Agriculture, Tainan, Taiwan \\ Corresponding author: C.Y. Lee \\ E-mail: culee@mail.npust.edu.tw
}

Genet. Mol. Res. 14 (2): 4381-4390 (2015)

Received May 28, 2014

Accepted October 29, 2014

Published April 30, 2015

DOI http://dx.doi.org/10.4238/2015.April.30.11

\begin{abstract}
Rice (Oryza sativa L.) is one of the most important food crops in the world. In Taiwan, due to the warm climate, there are two harvests annually. However, the yield and quality of rice can vary between each crop season in any given year. Previous reports have shown that microRNAs (miRNAs) play a crucial role in many developmental and physiological processes in plants. In this study, the heading date characteristics of 167 rice cultivars from the second crop season were recorded, and 27 rice cultivars were selected for preliminary microarray analysis. A total of 14 miRNAs from different heading date characteristics in 21 cultivars were selected based on significant differences in their expression profiles. Using a correlation analysis between the heading date and selected miRNA expression obtained from real-time polymerase chain reaction (PCR) assays, we developed a heading date prediction model. The model includes nine miRNA genes with corresponding $\mathrm{R} 2$ values of 0.8 . To confirm the model, a real-time
\end{abstract}


PCR analysis was performed on an additional 27 rice cultivars and we found the model predicted the heading date with accuracy. Therefore, the developed prediction may be useful in further studies aimed at confirming the reliability of the use of miRNA in molecular breeding and to increase the selection efficiency of rice cultivars and breeding.

Key words: Rice; miRNA; Heading date; Real-time PCR; Prediction model

\section{INTRODUCTION}

Rice (Oryza sativa L.) is one of main food crop cultivars in the world and the most important crop species in Taiwan. Because of the dramatic decrease in arable areas worldwide, crop yield is crucial. In particular, global climate change presents a serious challenge in terms of the breeding quality of high-yield rice cultivars that are adaptable to climate change. Although the sequencing of the rice genome was accomplished in 2002 (Goff et al., 2002) and the locations of genes that control important characteristics are now understood, finding the best ways to apply this information to rice breeding remains a significant issue. As such, increasing the yield and quality of rice remains an urgent problem for global agriculture and breeding programs and much work remains to identify the best methods to address these challenges rapidly and effectively.

MicroRNA (miRNA) is a small RNA molecule (between 20-24 nucleotides) that can regulate the expression of target genes through two different mechanisms (Hutvágner and Zamore, 2002; Jones-Rhoades et al., 2006). One mechanism involves the miRNA-mediated splicing of target genes and the other involves inhibiting the translation of the targets (Brodersen et al., 2008; Chapman and Carrington, 2007; Dunoyer et al., 2007). Since previous study has shown that the genes affected by miRNAs are involved in plant growth, development, and stress physiology (Mallory and Vaucheret, 2006), understanding its role in rice may provide key insight into the miRNA-mediated regulation of rice physiology.

The development and growth of higher plants can be divided into three phases: embryonic, vegetative, and reproductive. The transition between the vegetative and reproductive phases is a key step as it is when plants accumulate enough reserves to accommodate pollination and seed production. In rice, the flowering time directly influences grain production (Tsuji et al., 2013). The rice-flowering pathway includes four different stages: inflorescence initiation, development of the floral organs, panicle extrusion, and flower opening (Yoshida and Nagato, 2011).

Many factors regulate floral induction of plants, including environmental and physiological cues (Srikanth and Schmid, 2011). For example, floral induction of the dicotyledonous plant Arabidopsis thaliana is regulated by the gibberellin, autonomous, vernalization, and photoperiodic pathways. These pathways involve signal transduction process that stimulates flowering (Putterill et al., 2004; Yamaguchi and Abe, 2012) and previous studies have shown that some miRNAs are involved in flowering pathways (Jones-Rhoades et al., 2006). For example, miR172 is involved in the photoperiodic control of $A$. thaliana and the overexpression or knockout of its target APETALA 2-like (AP2) can delay the flowering time or cause the plant to flower early, respectively. These results indicate that AP2 plays an important role in plant flowering and in the genesis of floral organs (Aukerman and Sakai, 2003; Jung et al., 2007).

miR159 has also been shown to affect the GA-dependent flowering pathway of $A$. 
thaliana through its target genes, such as GAMYB, which are crucial for seed germination and flower development. Transgenic plants overexpressing miR159 exhibit delayed flowering, indicating that miR159 regulates plant flowering through GAMYB (Tsuji et al., 2006). Previous studies have identified the 3'-UTR of SPL3 (SPL gene, SQUAMOSA promoter-binding-like) as a target of miR156 in A. thaliana. Overexpression of the 3'-UTR-defective SPL3 led to early flowering, suggesting that SPL3 is involved in the formation and development of flowers (Cardon et al., 1997). Similar results have been published for rice where the overexpression of miR156 increased leaf numbers, induced late flowering, and inhibited apical dominance (Gandikota et al., 2007).

In recent studies, molecular models have enabled genomic selection for the prediction of genetic values in plants and animals (Crossa et al., 2010; de los Campos et al., 2012) and it was revealed that miRNA was a suitable molecular marker as it contains strong correlations between its expression profiling and the phenotypes observed (Lerebours et al., 2013). In this study, we have identified miRNA markers that predicted the heading date in rice, and may be used to improve breeding efficiency.

\section{MATERIAL AND METHODS}

\section{Material preparation}

Different cultivars of rice were grown at the Agricultural Research Institute in Sikou, Chiayi, and National Pingtung University of Science and Technology during 2009-2010. Phenotypes were recorded during the second crop season of the mature stage. Rice panicles were sampled at the booting stage (1-2 days before heading).

\section{Total and small RNA extraction}

Total RNA was extracted according to McCarty (1986). The RNA extraction buffer was prepared in TEN buffer (100 mM Tris, $20 \mathrm{mM}$ EDTA, $200 \mathrm{mM} \mathrm{NaCl}, \mathrm{pH} 9.0)$ with $20 \mathrm{mM}$ dithiothreitol (DTT), and contained $4 \mathrm{mM}$ 2-mercaptobenzothiazole. Mix saturated phenol (pH 4.5) with equal volumes was used to extract the RNA and $8 \mathrm{M}$ lithium chloride was used to precipitate the RNA. The RNA pellet was dissolved in DEPC-treated distilled water. The RNA concentration was measured using an infinite M200 PRO (TECAN, Switzerland) and stored at $-80^{\circ} \mathrm{C}$. Small RNA was extracted by precipitating the total RNA with polyethylene glycol.

\section{Small RNA reverse transcription}

The method of Varkonyi-Gasic et al. (2007) was used for reverse transcription. One microliter of the total RNA sample $(1 \mu \mathrm{g} / \mu \mathrm{L})$ was added to $11.2 \mu \mathrm{L}$ DEPC water and $0.5 \mu \mathrm{L}$ $10 \mathrm{nM}$ dNTP, and the mixture was reacted at $65^{\circ} \mathrm{C}$ for $5 \mathrm{~min}$ and then placed on ice for $2 \mathrm{~min}$. The mixture was centrifuged and $4 \mu \mathrm{L} 5 \mathrm{X}$ First-Strand buffer, $2 \mu \mathrm{L} 100 \mathrm{mM}$ DTT, $1 \mu \mathrm{L} 1 \mu \mathrm{M}$ reverse transcription primers, $0.1 \mu \mathrm{L}$ RNaseOUT, and $0.25 \mu \mathrm{L} 200 \mathrm{U} / \mu \mathrm{L}$ SuperScript III Reverse Transcriptase (Invitrogen) were added. The solution was mixed well and then placed on the PCR machine with the following temperature profile: $16^{\circ} \mathrm{C}$ for $30 \mathrm{~min}, 60$ cycles of $t 30^{\circ} \mathrm{C}$ for $30 \mathrm{~s}, 42^{\circ} \mathrm{C}$ for $30 \mathrm{~s}$, and $50^{\circ} \mathrm{C}$ for $1 \mathrm{~s}$, followed by $85^{\circ} \mathrm{C}$ for $5 \mathrm{~min}$. The reverse transcription products were stored at $-20^{\circ} \mathrm{C}$. 


\section{Real-time PCR}

For real-time PCR, $2 \mu \mathrm{L}$ reverse transcription product was added to $10 \mu$ TaqMan master mix (Roche Diagnostics Corp., Mannheim, Germany), $1 \mu \mathrm{L} 10 \mathrm{M}$ of each forward and reverse primers, and $0.2 \mu \mathrm{L}$ TaqMan probe $(10 \mu \mathrm{M})$ (Roche Diagnostics Corp., Mannheim, Germany). The solution was mixed well and analyzed by real-time PCR using a BIO-RAD CFX ConnectTM Real-Time System (Bio-Rad, USA). The reaction conditions were $95^{\circ} \mathrm{C}$ for $5 \mathrm{~min}, 40$ cycles of real-time PCR at $95^{\circ} \mathrm{C}$ for $15 \mathrm{~s}$ and $60^{\circ} \mathrm{C}$ for $1 \mathrm{~min}$.

\section{Prediction model development}

The flowering characteristics of 108 rice cultivars were grouped and aligned and 54 were randomly selected for correlational analysis between the miRNA real-time PCR data and flowering characteristics. The results of the correlation analysis were used to develop a prediction model for the heading date of rice. Statistical Analysis System (SAS) software (version 9.1.3; SAS ${ }^{\circledR}$ Institute, Cary, NC, USA) was used for the data analysis. The data were analyzed using the $t$-test. The correlation coefficient ( $\mathrm{r}$ ) was used to assess the strength of the linear correlations between the heading date and the expression of miRNA. Regression analysis was used to identify relationships between the response variable, heading date, and a set of miRNA genes. The coefficient of determination $\left(\mathrm{R}^{2}\right)$ was used to evaluate the goodness of fit of the regression as a prediction model. To select relevant miRNA genes, the backward elimination method was performed by discarding irrelevant miRNA genes.

\section{RESULTS}

To assess the expression levels of miRNA in the panicles of rice cultivars at the booting state, primers were designed for real-time PCR analysis according to the flow chart in Figure 1. From the real-time PCR analysis, 14 miRNAs were selected and used to train the model of the heading date by correlation analysis (Figure S1). To test the prediction model, the heading date of 27 additional rice cultivars in the booting state were predicted using the real-time PCR data of 9 miRNA (Figure S2). For training the model, 21 rice cultivars selected were classified into three groups according to their heading dates in the range of 56-78 days (Table 1). Fourteen genes belonging to 13 miRNA families were selected as molecular markers. These markers showed differential miRNA gene expression patterns between flowering groups according to microarray data (data not show). The reverse transcriptase and real-time PCR primer sequences of 14 miRNA genes were identified (Table 2). Of the 14 miRNAs analyzed by real-time PCR, only 5 miRNAs exhibited significantly different expression patterns between groups and had $\mathrm{R}^{2}$ values showing low correlations between the heading-date characteristics from each of the single miRNAs. Specially, while miRNA821a, miRNA439c, and miRNA395w did not demonstrate significantly different expression patterns with higher $\mathrm{R}^{2}$ values $(-0.37,0.28$, and 0.25 , respectively), miRNA426 and miRNA441 showed statistically significant differential expression with low $\mathrm{R}^{2}$ values $(0.22$ and 0.18$)$. Furthermore, we established the prediction model through the relationship of multiple-miRNAs expression profiles and heading date characteristics and $\mathrm{R}^{2}$ values reaching 0.8 , which included nine miRNA genes identified by quantitative-PCR data (Table 3). Unexpectedly, the prediction model recruited the miRNA171a despite containing no significant differential expression with low $\mathrm{R}^{2}$ 
value (0.09). To test this prediction model and investigate the heading date on the range of 64 to 74 days, an additional 27 rice cultivars were randomly collected and the expression patterns of the miRNA markers were analyzed at the booting stage using real-time PCR. According to the prediction model based on the miRNA data, the actual dates showed a best fit with the predicted dates with a difference of less than $3 \%$ (Table 4 ).

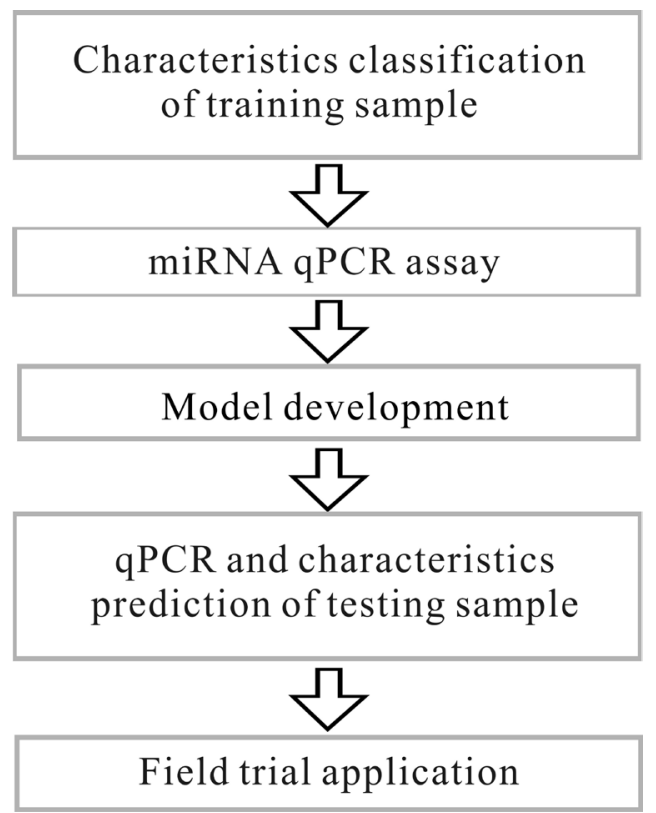

Figure 1. Flow chart identifying significant contributors to the miRNA prediction model.

Table 1. Twenty-one rice cultivars identified to train the prediction model of flowering characteristics.

\begin{tabular}{lcc}
\hline Cultivars & Heading date & Groups* \\
\hline Taichung 191 & 56 & I \\
Taichung 188 & 57 & I \\
Chia-nan 12 & 58 & I \\
Taichung Sen 2 & 60 & I \\
Kaohsiung 144 & 62 & I \\
Taichung 181 & 64 & I \\
Kaohsiung 25 & 65 & II \\
Nan Lu 2 & 67 & II \\
Tainung 72 & 68 & II \\
Taitung 27 & 69 & II \\
Tainan 11 & 72 & II \\
Tung Lu 3 & 72 & II \\
Chia-nan 4 & 72 & II \\
Tainung 40 & 73 & II \\
Taichung 179 & 75 & II \\
Taitung 30 & 75 & III \\
Tainan 7 & 75 & III \\
Taikeng 16 & 75 & III \\
Tung Lu 2 & 75 & III \\
Kaohsiung 137 & 75 & III \\
Taikeng 10 & 78 & III \\
\hline
\end{tabular}

*Flowering characteristics classified into three groups and aligned by flowering order from earliest to latest (I-III). 


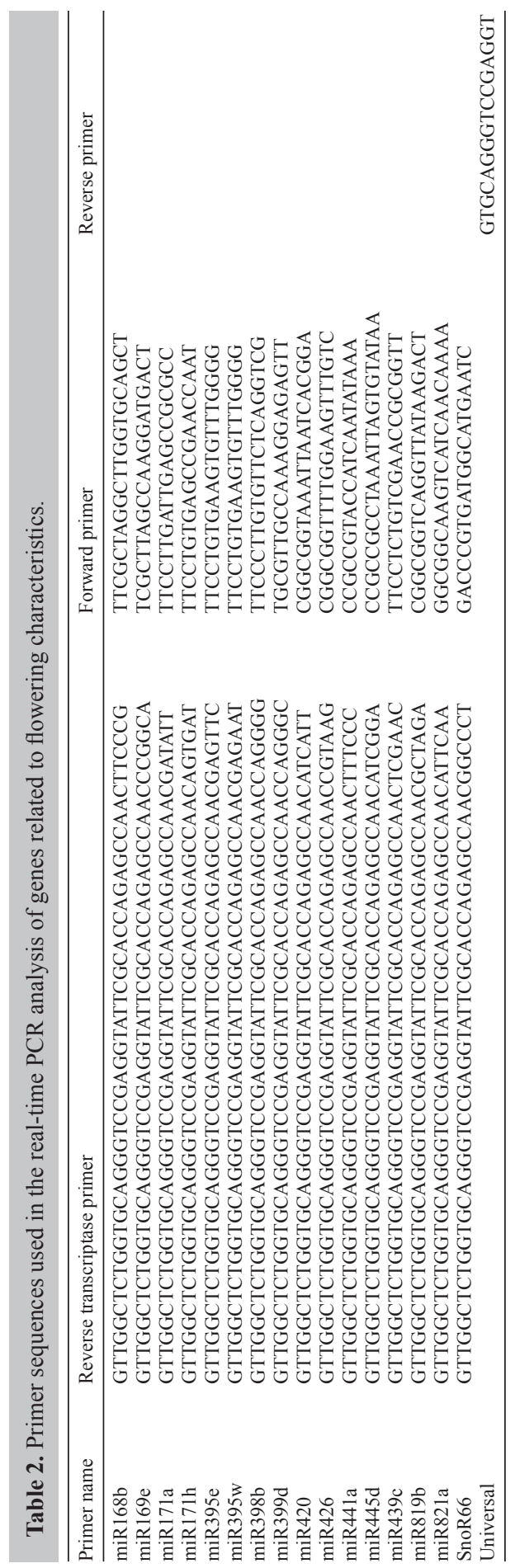




\begin{tabular}{|c|c|c|c|c|}
\hline miRNA & $\begin{array}{l}\text { T-test between } \\
\text { groups }(\mathrm{P}<0.05)\end{array}$ & $\begin{array}{l}\text { Expression ratio } \\
(>1.8 \text { ratio, }<0.6 \text { ratio })\end{array}$ & Correlation & Prediction model $\left(\mathrm{R}^{2}=0.8\right)$ \\
\hline miR168b & I \& II & (I \& II) & -0.20 & $\mathrm{Y}=73.28824-\mathrm{miR} 168 \mathrm{~b}(119.14385)+$ \\
\hline $\operatorname{miR} 169 \mathrm{e}$ & Not significant & Not significant & -0.1 & $\operatorname{miR} 171 \mathrm{a}(3.53705)+\operatorname{miR} 395 \mathrm{w}(1601.34495)-$ \\
\hline $\operatorname{miR} 171 \mathrm{a}$ & Not significant & Not significant & 0.09 & miR398b (2.5498) + miR420 (77815) - \\
\hline $\operatorname{miR} 395 \mathrm{e}$ & Not significant & Not significant & 0.11 & miR439c (19094) - miR445d (609.61014) - \\
\hline $\operatorname{miR} 395 w$ & Not significant & Not significant & 0.25 & $\operatorname{miR} 819 b(210.47437)+\operatorname{miR} 821 a(14.3485)$ \\
\hline $\operatorname{miR} 398 b$ & Not significant & Not significant & -0.14 & \\
\hline miR399d & Not significant & Not significant & -0.21 & \\
\hline $\operatorname{miR} 420$ & I \& II & (I \& II) & 0.28 & \\
\hline $\operatorname{miR} 426$ & I \& II & (I \& II) & 0.22 & \\
\hline $\operatorname{miR} 441 \mathrm{a}$ & I \& II & (I \& II) & 0.18 & \\
\hline $\operatorname{miR} 445 \mathrm{~d}$ & Not significant & Not significant & 0.09 & \\
\hline $\operatorname{miR} 439 c$ & Not significant & Not significant & 0.28 & \\
\hline $\operatorname{miR} 819 b$ & I \& III & (I \& III) & -0.46 & \\
\hline $\operatorname{miR} 821 \mathrm{a}$ & Not significant & Not significant & -0.37 & \\
\hline
\end{tabular}

Table 4. Twenty-seven rice cultivars used to test the prediction model.

\begin{tabular}{|c|c|c|c|}
\hline Cultivars & Real HD & Prediction HD & Variation \\
\hline Taipei 139 & 65 & 67 & $3.3 \%$ \\
\hline Taipei 177 & 66 & 69 & $4.5 \%$ \\
\hline Chia-nan 6 & 67 & 71 & $5.6 \%$ \\
\hline Taipei 301 & 68 & 69 & $1.4 \%$ \\
\hline Nan $\mathrm{Lu} 1$ & 68 & 68 & $0.3 \%$ \\
\hline Kaohsiung 24 & 68 & 72 & $6.5 \%$ \\
\hline HsinChu 50 & 69 & 72 & $4.3 \%$ \\
\hline HsinChu 55 & 69 & 71 & $3.3 \%$ \\
\hline Chia-nan 5 & 69 & 72 & $4.5 \%$ \\
\hline Taichung 153 & 69 & 71 & $2.3 \%$ \\
\hline Tainung 38 & 71 & 70 & $1.5 \%$ \\
\hline HsinChu 57 & 71 & 74 & $4.4 \%$ \\
\hline HsinChu 62 & 71 & 70 & $1.6 \%$ \\
\hline Taichung 189 & 72 & 70 & $3.2 \%$ \\
\hline Taichung Sel. 6 & 72 & 76 & $6.2 \%$ \\
\hline Taipei 311 & 72 & 70 & $3.0 \%$ \\
\hline Taitung Glutinous 31 & 72 & 71 & $1.6 \%$ \\
\hline Tainan 1 & 72 & 71 & $1.2 \%$ \\
\hline Taikeng 13 & 72 & 70 & $2.9 \%$ \\
\hline HsinChu 54 & 72 & 73 & $1.2 \%$ \\
\hline Chia-nan 10 & 72 & 70 & $2.9 \%$ \\
\hline Chia-nan 11 & 72 & 71 & $0.9 \%$ \\
\hline Chia-nan 13 & 72 & 72 & $0.4 \%$ \\
\hline Chia-nan 7 & 72 & 72 & $0.6 \%$ \\
\hline Chia-nan 8 & 72 & 72 & $0.2 \%$ \\
\hline Taipei 9 & 73 & 71 & $2.8 \%$ \\
\hline Taichung 114 & 74 & 70 & $5.1 \%$ \\
\hline Average & & & $2.8 \%$ \\
\hline
\end{tabular}

The model-predicted dates were compared to the real (practical) dates. HD: heading date.

\section{DISCUSSION}

In this study, the heading date prediction model based on the expression of nine miRNAs achieved a high R2 value for the correlations. However, data from single miRNAs could not predict the heading date in rice (Table 3). Although, previous studies have shown 
that plant miRNAs play key roles in many physiological processes (Mallory and Vaucheret, 2006; de Lima et al., 2012; Pashkovskiy and Ryazansky, 2013). But it is not easy to identify the major effect when one miRNA target multiple genes with different functions (Sieber et al., 2007; Kim et al., 2009; Hashimoto et al., 2013) and only a few miRNA targets have been confirmed in rice (Li et al., 2010). Therefore, further research is required for the relationships between the miRNAs and physiological characteristics.

To confirm our predictive model, we performed a bioinformatic search to identify miRNAs with a high possibility of involvement in the regulation of their target genes and flowering in rice. Through their target genes, the nine selected miRNAs contained different functions, such as plant growth, development, and metabolism. For example, the target gene of miR171 is a member of the GRAS transcription factor family and it has been shown that the loss of one its homologous genes, HAM, induced early flowering in Petunia hybrida (Stuurman et al., 2002). Additionally, miR171 is significantly expressed in the flower organ of A. thaliana and it has been predicted to function in flower development (Llave et al., 2002). On the other hand, the target genes of miR171c have been shown to regulate shoot branching and influence leaf and flower pattering in Arabidopsis (Wang et al., 2010), while miR395 is involved in the regulation of sulfur absorption (Kawashima et al., 2011). The target gene of miR398 in Arabidopsis is related to the photooxidative reaction (Dugas and Bartel, 2008), whereas others such as miR819 and miR168 (through ARGONAUTE 1) are involved in brassinosteroid homeostasis in plants (Peng et al., 2013) and the regulation of miRNA expression (Várallyay et al., 2010), respectively. Target genes have also been implicated in the regulation of the abiotic stress responses in plants. For example, miR821 is associated with low-N tolerance in rice (Nischal et al., 2012) whereas the function of other miRNAs such as miR420, miR439, and miR445 require further investigation. However, through their target genes, most of the nine rice miRNAs identified in this study act as regulators of growth, development, and stress physiology.

Our results showed that single miRNAs, either directly or indirectly, are not effective determinants of rice heading dates. Therefore, through regression analysis of the miRNA expression from training and testing, 9 miRNAs can apply a better correlation and prediction for the heading-date characteristic of rice in booting stage.

\section{CONCLUSIONS}

In this study, a real-time PCR correlation analysis identified 9 of 14 miRNAs to be involved in controlling the flowering dates in the reproductive phase that precedes heading. Following this, rapid and effective miRNA-based prediction models can be developed. Importantly, this method may provide a platform for increasing the efficiency of breeding, selection, and cultivation of rice cultivars.

\section{ACKNOWLEDGMENTS}

We are grateful to Council of Agriculture, Executive Yuan, R.O.C. (Taiwan) for providing funds with grant \#99AS-4.2.1-FD-Z1 and \#100AS-4.2.1-FD-Z1. We also thank Dr. Ching-Hsiang Hsieh, Department of Agronomy, Department of Plant Industry, National Pingtung University of Science \& Technology, for providing experimental space. 
miRNA-based prediction model for rice heading date characteristics

\section{Supplementary material}

\section{REFERENCES}

Aukerman MJ and Sakai H (2003). Regulation of flowering time and floral organ identity by a microRNA and its APETALA2-like target genes. Plant Cell 15: 2730-2741.

Brodersen P, Sakvarelidze-Achard L, Bruun-Rasmussen M, Dunoyer P, et al. (2008). Widespread translational inhibition by plant miRNAs and siRNAs. Science 320: 1185-1190.

Cardon GH, Höhmann S, Nettesheim K, Saedler H, et al. (1997) Functional analysis of the Arabidopsis thaliana SBP-box gene SPL3: a novel gene involved in the floral transition. Plant J. 12: 367-377.

Chapman EJ and Carrington JC (2007). Specialization and evolution of endogenous small RNA pathways. Nat. Rev. Genet. 8: 884-896.

Crossa J, Campos G de L, Pérez P, Gianola D, et al. (2010). Prediction of genetic values of quantitative traits in plant breeding using pedigree and molecular markers. Genetics 186: 713-724.

de Lima JC, Loss-Morais G and Margis R (2012). MicroRNAs play critical roles during plant development and in response to abiotic stresses. Genet. Mol. Biol. 35: 1069-1077.

de los Campos G, Klimentidis YC, Vazquez AI and Allison DB (2012). Prediction of expected years of life using wholegenome markers. PLoS One 7: e40964.

Dugas DV and Bartel B (2008). Sucrose induction of Arabidopsis miR398 represses two Cu/Zn superoxide dismutases. Plant Mol. Biol. 67: 403-417.

Dunoyer P, Himber C, Ruiz-Ferrer V, Alioua A, et al. (2007). Intra- and intercellular RNA interference in Arabidopsis thaliana requires components of the microRNA and heterochromatic silencing pathways. Nat. Genet. 39: 848-856.

Gandikota M, Birkenbihl RP, Höhmann S, Cardon GH, et al. (2007). The miRNA156/157 recognition element in the 3'UTR of the Arabidopsis SBP box gene SPL3 prevents early flowering by translational inhibition in seedlings. Plant J. 49: 683-693.

Goff SA, Ricke D, Lan TH, Presting G, et al. (2002). A draft sequence of the rice genome (Oryza sativa L. ssp. japonica) Science 5: 92-100.

Hashimoto Y, Akiyama Y and Yuasa Y (2013). Multiple-to-multiple relationships between microRNAs and target genes in gastric cancer. PLoS One 8: e62589.

Hutvágner G and Zamore PD (2002). A microRNA in a multiple-turnover RNAi enzyme complex. Science 297: 20562060.

Jones-Rhoades MW, Bartel DP and Bartel B (2006). MicroRNAs and their regulatory roles in plants. Annu. Rev. Plant. Biol. 57: 19-53.

Jung JH, Seo YH, Seo PJ, Reyes JL, et al. (2007). The GIGANTEA-regulated microRNA172 mediates photoperiodic flowering independent of CONSTANS in Arabidopsis. Plant Cell 19: 2736-2748.

Kawashima CG, Matthewman CA, Huang S, Lee BR, et al. (2011). Interplay of SLIM1 and miR395 in the regulation of sulfate assimilation in Arabidopsis. Plant J. 66: 863-876.

Kim JH, Woo HR, Kim J, Lim PO, et al. (2009). Trifurcate feed-forward regulation of age-dependent cell death involving miR164 in Arabidopsis. Science 323: 1053-1057.

Lerebours F, Cizeron-Clairac G, Susini A, Vacher S, et al. (2013). MiRNA expression profiling of inflammatory breast cancer identifies a 5-miRNA signature predictive of breast tumor aggressiveness. Int. J. Cancer 133: 1614-1623.

Li YF, Zheng Y, Addo-Quaye C, Zhang L, et al. (2010). Transcriptome-wide identification of microRNA targets in rice. Plant J. 62: 742-759.

Llave C, Xie Z, Kasschau KD and Carrington JC (2002). Cleavage of Scarecrow-like mRNA targets directed by a class of Arabidopsis miRNA. Science 297: 2053-2056.

Mallory AC and Vaucheret H (2006). Functions of microRNAs and related small RNAs in plants. Nat. Genet. 38: 850.

McCarty D (1986). A simple method for the extraction of RNA from maize tissue. Maize Genet. Coop. Newslett. 60: 61.

Nischal L, Mohsin M, Khan I, Kardam H, et al. (2012). Identification and comparative analysis of microRNAs associated with low-N tolerance in rice genotypes. PLoS One 7: e50261.

Pashkovskiy PP and Ryazansky SS (2013). Biogenesis, evolution, and functions of plant microRNAs. Biochemistry 78: 627-637.

Peng T, Sun H, Du Y, Zhang J, et al. (2013). Characterization and expression patterns of microRNAs involved in rice grain filling. PLoS One 8: e54148.

Putterill J, Laurie R and Macknight R (2004). It's time to flower: the genetic control of flowering time. Bioessays 26 : 363-373. 
Sieber P, Wellmer F, Gheyselinck J, Riechmann JL, et al. (2007). Redundancy and specialization among plant microRNAs: role of the MIR164 family in developmental robustness. Development 134: 1051-1060.

Srikanth A and Schmid M (2011). Regulation of flowering time: all roads lead to Rome. Cell Mol. Life Sci. 68: 2013-2037. Stuurman J, Jäggi F and Kuhlemeier C (2002). Shoot meristem maintenance is controlled by a GRAS-gene mediated signal from differentiating cells. Genes Dev. 16: 2213-2218.

Tsuji H, Aya K, Ueguchi-Tanaka M, Shimada Y, et al. (2006). GAMYB controls different sets of genes and is differentially regulated by microRNA in aleurone cells and anthers. Plant J. 47: 427-444.

Tsuji H, Taoka K and Shimamoto K (2013). Florigen in rice: complex gene network for florigen transcription, florigen activation complex, and multiple functions. Curr. Opin. Plant Biol. 16: 228-235.

Várallyay E, Válóczi A, Agyi A, Burgyán J, et al. (2010). Plant virus-mediated induction of miR168 is associated with repression of ARGONAUTE1 accumulation. EMBO J. 29: 3507-3519.

Varkonyi-Gasic E, Wu R, Wood M, Walton EF, et al. (2007). Protocol: a highly sensitive RT-PCR method for detection and quantification of microRNAs. Plant Methods 3: 12.

Wang L, Mai YX, Zhang YC, Luo Q, et al. (2010). MicroRNA171c-targeted SCL6-II, SCL6-III, and SCL6-IV genes regulate shoot branching in Arabidopsis. Mol. Plant. 3: 794-806.

Yamaguchi A and Abe M (2012). Regulation of reproductive development by non-coding RNA in Arabidopsis: to flower or not to flower. J. Plant Res. 125: 693-704.

Yoshida H and Nagato Y (2011). Flower development in rice. J. Exp. Bot. 62: 4719-4730. 